\title{
Keragaman dan Kebutuhan Teknologi Pakan Peternak Sapi Perah di Kabupaten Enrekang
}

\author{
Variety and Need of Feed Technology of Small-scale Dairy Farmer in Enrekang Regency
}

\author{
S. Baba ${ }^{a},{ }^{*}$ A. Muktiani ${ }^{b}$, A. Ako ${ }^{a}$, \& M. I. A. Dagong ${ }^{a}$ \\ aFakultas Peternakan, Universitas Hasanuddin \\ Jln. Perintis Kemerdekaan Km. 10 Tamalanrea Makassar \\ ${ }^{\mathrm{b}}$ Fakultas Peternakan, Universitas Diponegoro \\ Jln. Prof. A. Soedarto, SH. Tembalang, Semarang \\ (Diterima 12-07-2010; disetujui 19-04-2011)
}

\begin{abstract}
ABSTRAK
Pemahaman yang tepat terhadap potensi, permasalahan, dan kebutuhan peternak tentang teknologi pakan dapat meningkatkan adopsi teknologi oleh peternak. Tujuan penelitian ini adalah untuk mengetahui potensi, permasalahan, dan kebutuhan peternak skala kecil akan teknologi pakan menurut preferensi suami dan istri. Metode yang digunakan adalah dengan memodifikasi metode participatory rural appraisal (PRA), seperti participatory mapping untuk mengetahui potensi, dan preference rangking untuk mengetahui prioritas masalah dan kebutuhan. Penerapan PRA sebanyak 4 kali selama bulan April-September 2009 di Kabupaten Enrekang yang dibagi menjadi wilayah sentra dan nonsentra. Preferensi petani terhadap potensi dan masalah tidak berbeda antara suami dan istri, hanya kebutuhan teknologi yang berbeda. Potensi sumber hijauan utamanya rumput di daerah sentra lebih beragam dibanding daerah nonsentra, namun potensi sumber konsentrat lebih banyak di daerah nonsentra. Kurangnya pengetahuan formulasi pakan dan konsentrat untuk sapi perah, tidak diketahuinya manfaat bahan pakan, serta rendahnya kualitas pakan di musim kemarau adalah masalah utama peternak di daerah sentra. Masalah utama peternak di daerah nonsentra adalah tidak diketahuinya pengawetan pakan, kurangnya tenaga kerja, dan pakan yang tidak mencukupi sepanjang tahun. Kebutuhan teknologi di daerah sentra adalah peningkatan pengetahuan formulasi bahan pakan lokal untuk produksi konsentrat dan complete feed adalah prioritas utama. Daerah nonsentra lebih memprioritaskan pengawetan limbah dan bahan pakan menjadi complete feed pada musim hujan/panen.
\end{abstract}

Kata kunci: sapi perah, teknologi pakan, participatory rural appraisal, skala kecil

\section{ABSTRACT}

An appropriate understanding towards preference of small-scale dairy producers can improve technology adoption. The objective of this study was to understand potential, problem and need of small-scale dairy producers including farmer and his wife. The method used was modification of participatory rural appraisal (PRA) like participatory mapping to detect potential, and Preference ranking to understand problem and need priority. PRA applications were six times during AprilSeptember 2009 at central area and non-central area in Enrekang regency. Preference of farmer and his wife toward potential and problem were not different. Only feed technology need was different. Forage sources at central area were more diverse than non-central area but concentrate sources at noncentral area were more than central area. Lack of knowledge for feed and concentrate formulation and nutritional requirements, less known of feed use, and low feed quality at dry season were the main problems at central area. At non-central area, lack of knowledge for preserving feed, lack of labour, and feed shortage at dry season were main problem faced by farmers. Knowledge improvement for local feed and complete-feed formulation are priority technology at central area. At non-central area, agricultural waste and forage preserving and complete-feed are needed by farmer.

Key words: dairy cattle, feed technology, participatory rural appraisal, small scale

\footnotetext{
* Korespondensi:

Telp. 0411-587217; e-mail: syahdar baba@yahoo.com
} 


\section{PENDAHULUAN}

Kontribusi biaya pakan (hijauan dan konsentrat) dalam produksi setiap liter susu mencapai 62,5\% (Yusdja, 2005). Menurut Mudikdjo et al. (2001), dibutuhkan 32,41\% biaya konsentrat untuk memproduksi setiap liter susu. Tingginya biaya pakan sering menjadi kendala bagi peternak dalam memenuhi kebutuhan nutrisi sapi yang dipelihara. Jika peternak dapat menggunakan pakan berkualitas dengan harga yang lebih murah, maka usaha sapi perah dapat memberikan keuntungan yang lebih layak bagi usaha yang dilaksanakan. Berdasarkan hal tersebut, diperlukan upaya menyediakan teknologi yang sesuai dengan kebutuhan peternak dengan harga yang murah melalui pemanfaatan potensi pakan lokal.

Usaha sapi perah di Kabupaten Enrekang memiliki karakteristik yang berbeda dengan usaha sapi perah di Pulau Jawa. Peternak tidak menjual susu segar tetapi mengolahnya menjadi dangke, sejenis makanan tradisional (lauk), yang telah dikonsumsi turun temurun. Jumlah peternak skala kecil (1-3 ekor) mencapai 91\% dengan produktivitas rata-rata 5 liter/ekor/hari (Dinas Pertanian Enrekang, 2008). Rendahnya produktivitas disebabkan adopsi teknologi pakan yang rendah serta manajemen pemeliharaan yang tradisional (Baba, 2008).

Rendahnya adopsi teknologi disebabkan pengembangan teknologi di level usahatani masih menggunakan pola top down. Peneliti mengembangkan teknologi menurut sudut pandang mereka yang dilanjutkan oleh penyuluh untuk ditransfer ke peternak tanpa melalui proses adaptasi (Biggs \& Smith, 1998; Loader \& Amartya, 1999). Kendalanya adalah teknologi tersebut tidak dikembangkan berdasarkan potensi, permasalahan dan kebutuhan teknologi peternak, terutama peternak skala kecil (Hagman et al., 1999). Peneliti mengembangkan teknologi di pusat penelitian ataupun melakukan adaptasi teknologi bersama dengan peternak maju yang kondisi usahatani dan sumber dayanya sangat berbeda dengan peternak skala kecil (Altieri, 2002; Peacock, 2005; Chambers 1994; 2007), akibatnya peternak skala kecil tidak mampu mengadopsi teknologi yang dikembangkan (Walters et al., 1999).

Salah satu metode untuk menggali potensi, permasalahan dan kebutuhan peternak yang efektif dan efisien adalah metode participatory rural appraisal (PRA). Metode ini membalik paradigma top down dengan menempatkan peternak skala kecil sebagai orang yang paling memahami potensi, masalah, dan kebutuhan mereka. Peneliti, penyuluh, dan peternak berinteraksi pada posisi yang setara sehingga diperoleh pemahaman yang sama terhadap apa yang dihadapi oleh peternak skala kecil. Penyuluh dan peneliti menjadi fasilitator peternak dalam mengungkapkan apa yang dihadapi. Peneliti menjadi sumber pengetahuan bagi peternak dan penyuluh. Melalui penggunaan metode PRA dapat dilahirkan sintesis teknologi atas permasalahan yang dihadapi oleh peternak skala kecil menurut perspektif mereka (Rekhis et al., 2007; Shamsuddin et al., 2007; Vaarst et al., 2007).

Penelitian ini bertujuan untuk mengidentifikasi potensi, permasalahan dan kebutuhan teknologi pakan peternak sapi perah skala kecil menurut perspektif suami dan istri dengan menggunakan metode PRA. Atas dasar pemahaman potensi dan permasalahan serta kebutuhan teknologi pakan menurut perspektif peternak, dapat diciptakan paket teknologi yang dapat dikembangkan oleh peternak untuk diadaptasikan dalam usahatani mereka. Pelibatan suami dan istri karena proses adopsi teknologi merupakan keputusan bersama dalam sebuah keluarga usahatani (Chi et al., 2007).

\section{METODE}

Penelitian dilaksanakan di Kecamatan Cendana (sentra pengembangan sapi perah) dan Kecamatan Anggeraja, Alla, Baraka, dan Malua (nonsentra pengembangan sapi perah) Kabupaten Enrekang. Pembagian wilayah berdasarkan pada karakteristik wilayah yang berbeda. Daerah sentra merupakan dataran rendah (100 $\mathrm{m}$ dpl) dan sentra tanaman palawija, sementara daerah nonsentra merupakan daerah pegunungan (+500 m dpl) dan sentra hortikultura sehingga potensi pakannya berbeda.

Penelitian dilakukan dengan mengadopsi metode PRA yang dikembangkan oleh Chambers (1994) dan dimodifikasi oleh Devendra (2007) pada usahatani sapi perah. Metode participatory mapping dan indepth study digunakan untuk mengetahui potensi wilayah sapi perah. Peserta yang terlibat dalam participatory mapping terdiri atas 2 tenaga ahli (penyuluhan dan produksi ternak perah), Kepala Sub Dinas Peternakan Enrekang, 4 orang penyuluh (masing-masing 2 orang di setiap daerah), serta 10 pasang suami-istri peternak sentra dan nonsentra. Participatory mapping dilaksanakan 2 kali, yaitu 1 kali di daerah sentra dan 1 kali di daerah nonsentra. Seorang peternak menggambarkan wilayah pengembangan usaha sapi perah yang dilengkapi oleh peternak lainnya. Tenaga ahli, birokrasi, dan penyuluh memfasilitasi peternak menggambarkan peta wilayah dengan tepat. Tahapan ini merupakan langkah awal untuk memancing partisipasi peternak dalam mengidentifikasi potensi, permasalahan, dan kebutuhan mereka. Hasil participatory mapping diklarifikasi melalui indepth study di daerah sentra dan nonsentra. Tenaga ahli melakukan survei langsung ke setiap daerah bersama penyuluh dan peternak. Kegiatan ini dilakukan sepanjang bulan April-Mei 2009.

Penggalian prioritas permasalahan dan kebutuhan pakan yang dirasakan peternak dilakukan dengan metode modifikasi matriks prioritas masalah dan kebutuhan melalui preference ranking (Mikkelsen, 2003). Rangkaian kegiatan dilakukan sebanyak 4 kali, yaitu masing-masing 2 kali di daerah sentra dan nonsentra (suami dan istri terpisah) pada bulan AgustusSeptember 2009. Peserta terdiri atas 4 orang ahli dengan bidang keahlian penyuluhan, formulasi pakan, hijauan, dan produksi sapi perah, dan 10 orang pasang suamiistri peternak. Pemilihan peternak berdasarkan diskusi dengan dinas peternakan, kelompok tani ternak, dan penyuluh. Kriteria yang digunakan adalah skala usaha maksimal 3 ekor, pengalaman usaha minimal 5 tahun, mengetahui permasalahan pakan di daerahnya, serta mampu baca tulis. 
Prosedur penentuan masalah dan kebutuhan diawali dengan memberikan penjelasan mengenai aturan dan materi yang akan didiskusikan. Selanjutnya, peternak diberi kesempatan menulis dan memaparkan semua permasalahan dan kebutuhan tentang pakan yang dirasakan dalam mengelola usaha sapi perah. Terdapat 8 masalah dan 7 kebutuhan prioritas yang dirasakan oleh peternak (suami dan istri) yang diperoleh dari hasil pemaparan, baik di daerah sentra, maupun nonsentra. Tenaga ahli membantu peternak merumuskan dan memilah masalah dan kebutuhan yang telah dipaparkan oleh peternak. Berdasarkan hasil perumusan tenaga ahli, peternak diberi kesempatan untuk memberikan rangking terhadap masalah (skor tertinggi 8, terendah 1) dan kebutuhan teknologi pakan (skor tertinggi 7, terendah 1) dengan memberikan skor tertinggi terhadap permasalahan dan kebutuhan yang dirasakan. Hasil perangkingan yang ditandai dengan skor tertinggi menggambarkan masalah dan kebutuhan yang paling tinggi prioritasnya sampai dengan yang paling rendah prioritasnya menurut preferensi peternak. Perangkingan dilakukan guna menemukan masalah utama serta kebutuhan prioritas yang dirasakan oleh peternak agar dalam penyusunan materi penyuluhan dapat memenuhi kebutuhan peternak.

\section{HASIL DAN PEMBAHASAN}

\section{Karakteristik Peternak dan Usahatani Peserta PRA}

Umur peternak pada umumnya usia produktif, baik di daerah sentra, maupun nonsentra.Tingkat pendidikan di daerah sentra rata-rata SMA, sementara di daerah nonsentra SD/SMP dan SMA. Terdapat $85 \%$ responden yang tingkat ketergantungannya 50\%-100\% dari usaha sapi perah. Mereka ini utamanya peternak dengan skala usaha 2-3 ekor. Jumlah anggota keluarga berada pada kisaran 2-6 orang (Tabel 1).

Meskipun skala usaha hanya 2-3 ekor namun ketergantungan peternak terhadap usaha sapi perah sudah tinggi, yaitu 50\%-100\%. Hanya peternak skala 1 ekor dan 2 ekor masih mengerjakan pekerjaan lain seperti tanaman pangan (padi, jagung dan kacang tanah) di daerah sentra dan hortikultura (bawang merah, wortel) serta perkebunan (kakao dan kopi) di daerah nonsentra. Hal ini disebabkan tingginya harga dangke yang diterima peternak, yaitu Rp10.000 per biji yang jika dikonversi ke harga susu setara Rp6.000-Rp6.500 per liter. Harga ini dua kali lebih tinggi dibanding harga susu di Pulau Jawa pada waktu yang sama, yaitu Rp2.000-Rp2.700/liter. Dorongan peternak memelihara sapi perah cukup tinggi (skala 2-3 ekor) sehingga sudah tidak mengusahakan usaha lain. Antusiasme peternak baru untuk memelihara sapi perah juga dibuktikan oleh pertumbuhan populasi sebesar 197\% dari 432 ekor pada tahun 2002 menjadi 1.283 ekor pada tahun 2007 (Dinas Peternakan Enrekang, 2008).

Penanganan usaha sapi perah pada kegiatan upstream agribussiness (penyediaan sarana produksi) seperti penyediaan lahan tanaman pakan, penyediaan dan pengelolaan pakan, penyediaan pelayanan dan sarana inseminasi buatan dan kesehatan ternak lebih banyak dikerjakan oleh suami, baik di daerah sentra $(83,4 \%)$, maupun nonsentra $(88,6 \%)$ dibanding istri (16,6\% di daerah sentra dan $11,4 \%$ di daerah nonsentra). Tanggung jawab istri meningkat pada kegiatan on farm meliputi pemberian pakan dan pembersihan kandang pada pagi hari. Pemerahan susu pada pagi hari sebagian dilakukan istri dan sebagian lagi oleh suami. Sore hari, aktivitas pemberian pakan, pembersihan kandang dan pemerahan susu dikerjakan suami. Aktivitas pada sub -sistem downstream agribusiness (pengolahan produk dan pemasaran) yang meliputi pengolahan dan pemasaran dangke dilakukan istri, baik di daerah sentra, maupun nonsentra. Suami hanya terlibat dalam mengantarkan dangke ke konsumen atau ke pedagang pengecer. Jika ada tenaga kerja lain yang terlibat (misalnya anak atau tenaga kerja yang disewa) hanya bertanggung jawab memberikan pakan dan membersihkan kandang (Tabel 1).

Keterlibatan istri dalam usaha sapi perah skala kecil telah diteliti oleh Mastuti \& Hidayat (2009) di Banyumas yang menunjukkan bahwa perempuan (istri) terlibat $25,24 \%$ dalam pengelolaan usahanya. Hasil penelitian Gomez et al. (2007) menyebutkan angka 22\% keterlibatan istri di Peru. Keterlibatan istri di Kabupaten Enrekang cukup tinggi, terutama pada subsistem downstream agribusiness yang mencapai $90 \%$. Keterlibatan istri dalam usahatani yang tinggi menurut Chi et al. (2007) mempengaruhi karakteristik teknologi yang dibutuhkan dan keputusan adopsi teknologi oleh rumah tangga petani.

\section{Topografi Wilayah}

Wilayah yang menjadi sentra pengembangan sapi perah di Kabupaten Enrekang terletak di Kecamatan Cendana yang meliputi empat desa, yaitu Desa Pinang, Desa Lebang, Kelurahan Cendana dan Desa Pundi Lemo. Jumlah populasi terbesar terdapat di Desa Pinang dan Desa Lebang mencapai $70 \%$ dari total populasi Kecamatan Cendana. Keempat desa ini terletak di daerah aliran sungai (DAS) Saddang yang merupakan sungai terpanjang di Sulawesi Selatan. Peternak menanam rumput untuk kebutuhan ternaknya di sepanjang DAS Saddang. Selain itu keberadaan tanaman utama seperti jagung di lahan kering, serta padi dan kacang tanah di lahan sawah merupakan salah satu sumber pakan yang dapat dimanfaatkan peternak.

Pemeliharaan ternak dilakukan di dekat rumah dengan alasan keamanan dan kemudahan dalam menangani ternak. Peternak yang rumahnya jauh dari aliran sungai melakukan penanaman rumput dengan mengkonversi tanaman perkebunan (cokelat) yang terkena penyakit PBK (penggerek buah kakao) atau di lahan kering. Jumlah peternak yang menanam jenis rumput lain seperti rumput benggala $20 \%$, setaria $40 \%$, dan kolonjono 60\%. Rumput lapangan diperoleh di sekitar sawah dan dekat hutan.

Peternak di daerah nonsentra tersebar di pegunungan yang merupakan sentra pengembangan hortikultura dan perkebunan. Terdapat empat kecamatan yang menjadi daerah baru pengembangan sapi perah, yaitu Kecamatan Anggeraja, Baraka, Malua, dan Alla. Terdapat pula STA (sub terminal agribisnis) di 
Tabel 1. Karakteristik peternak yang menjadi partisipan dalam pelaksanaan participatory rural appraisal di Kabupaten Enrekang, Sulawesi Selatan, 2009

\begin{tabular}{|c|c|c|c|c|}
\hline \multirow{2}{*}{ Parameter } & \multicolumn{2}{|c|}{ Sentra } & \multicolumn{2}{|c|}{ Non sentra } \\
\hline & Suami & Istri & Suami & Istri \\
\hline \multicolumn{5}{|l|}{ Umur } \\
\hline$<25$ tahun & 0 & 0 & 0 & 0 \\
\hline $25-50$ tahun & 10 & 10 & 9 & 10 \\
\hline$>50$ tahun & 0 & 0 & 1 & 0 \\
\hline \multicolumn{5}{|l|}{ Pendidikan } \\
\hline SD-SMP & 2 & 1 & 4 & 6 \\
\hline SMA & 7 & 9 & 5 & 4 \\
\hline PT & 1 & 0 & 1 & 0 \\
\hline \multicolumn{5}{|c|}{ Jumlah anggota keluarga } \\
\hline $2-4$ orang & \multicolumn{2}{|c|}{2} & \multicolumn{2}{|c|}{4} \\
\hline 5-6 orang & \multicolumn{2}{|c|}{7} & \multicolumn{2}{|c|}{4} \\
\hline$>6$ orang & \multicolumn{2}{|c|}{1} & \multicolumn{2}{|c|}{2} \\
\hline \multicolumn{5}{|c|}{ Ketergantungan pada usaha sapi perah } \\
\hline $100 \%$ & \multicolumn{2}{|c|}{3} & \multicolumn{2}{|c|}{1} \\
\hline $50 \%$ & \multicolumn{2}{|c|}{4} & \multicolumn{2}{|c|}{9} \\
\hline$<50 \%$ & \multicolumn{2}{|c|}{3} & \multicolumn{2}{|c|}{0} \\
\hline \multicolumn{5}{|c|}{$\%$ Keterlibatan dalam usaha* } \\
\hline Off farm hulu & 83,40 & 16,60 & 88,60 & 11,40 \\
\hline On farm & 62,20 & 37,80 & 74,10 & 25,90 \\
\hline Off farm hilir & 8,70 & 91,30 & 2,20 & 97,80 \\
\hline
\end{tabular}

Keterangan: *Dihitung berdasarkan rata-rata persentase jam kerja per hari antara suami dan istri.

Kecamatan Alla yang dibangun oleh pemerintah sebagai pusat transaksi komoditi hortikultura antara petani, pedagang antarkabupaten dan pedagang antarpulau.

Jumlah responden yang berdomisili di sepanjang aliran sungai Mata Allo adalah 60\% yang melintasi empat kecamatan tersebut sementara sisanya (40\%) di pegunungan. Peternak menanam rumput gajah di pinggir sungai untuk mencegah longsor serta sebagai sumber pakan. Peternak yang memelihara sapi di pegunungan menanam rumput di sekitar lahan perkebunannya agar memudahkan memperoleh pakan.

Pengembangan usaha sapi perah di sepanjang aliran sungai memberikan kemudahan bagi peternak untuk memperoleh air, memperoleh hijauan dari daerah aliran sungai, serta memudahkan membuang feses. Namun demikian, ancaman pencemaran air akibat pembuangan limbah ke sungai justru semakin meningkat. Penelitian Thabrew et al. (2009) menunjukkan bahwa pembuangan limbah feses dan urin ke sungai menyebabkan pencemaran air tanah yang menjadi sumber air bagi masyarakat. Havlikova et al. (2008) menunjukkan emisi amonia $\left(\mathrm{NH}_{3}\right)$, nitrogen oksida $(\mathrm{NO})$, nitrat $\left(\mathrm{NO}_{3}\right)$, dan fosfat $\left(\mathrm{PO}_{4}\right)$ akibat pembuangan feses ke air menyebabkan tingginya toksisitas bagi manusia di Republik Czech. Oleh karena itu perlu program penyadaran untuk mengolah limbah agar tidak merusak lingkungan, serta memberikan pendapatan tambahan bagi peternak.

\section{Potensi Pakan}

Potensi pakan dapat dilihat dari jenis pakan yang digunakan, ketersediaan, serta kemudahan untuk diakses peternak skala kecil. Jenis rumput yang sering digunakan peternak di daerah sentra ada 5 jenis, yaitu rumput gajah, kolonjono, setaria, benggala, dan rumput lapangan, sementara di daerah nonsentra ada 3, yaitu rumput gajah, raja, dan setaria (Tabel 2). Rumput yang umum digunakan adalah rumput gajah, baik di daerah sentra, maupun nonsentra. Semua peternak mempunyai kebun rumput gajah dan atau memanfaatkan daerah aliran sungai untuk menanam rumput gajah. Rumput lain atau sumber hijauan lain hanya digunakan untuk mensubstitusi atau melengkapi rumput gajah yang diberikan. Proses substitusi rumput gajah dengan sumber hijauan lainnya hanya coba-coba.

Limbah pertanian yang sering digunakan sebagai sumber hijauan di daerah sentra adalah limbah tanaman pangan karena merupakan daerah sentra tanaman pangan, seperti padi, kacang tanah, dan jagung. Pemanfaatan jerami padi dan jagung hanya dilakukan jika musim kemarau. Jerami kacang tanah dimanfaatkan oleh seluruh peternak daerah sentra ketika musim panen (akhir musim hujan) karena mampu meningkatkan produksi susu secara signifikan.

Pemanfaatan limbah perkebunan sebagai sumber hijauan seperti kulit kopi, kulit kakao, batang pepaya, 
dan batang pisang dilakukan oleh peternak nonsentra karena merupakan sentra perkebunan dan hortikultura. Pemanfaatan limbah perkebunan hanya pada musim kemarau, saat rumput gajah tidak dapat dipotong lagi (Tabel 2). Sumber hijauan lain yang dimanfaatkan adalah limbah hortikultura seperti limbah wortel dan kol. Terdapat $20 \%$ responden yang berdomisili di dekat STA (Sub Terminal Agribisnis) Enrekang yang merupakan pusat perdagangan hortikultura, yang memanfaatkan limbahnya ataupun hasil sortiran dan tanaman yang tidak laku. Daun ubi jalar dimanfaatkan seluruh peternak nonsentra karena mampu meningkatkan produksi susu dan dangke. Produksinya sangat melimpah di akhir musim hujan, yaitu bulan Juni sampai September setiap tahunnya.

Limbah tanaman yang belum dimanfaatkan oleh peternak nonsentra adalah limbah tanaman singkong, berupa daun singkong sisa panen. Erwanto et al. (2001) menyatakan daun singkong mengandung asam amino bercabang (valina, isoleusina, dan leusina) yang tinggi.

Tabel 2. Jumlah peternak yang menggunakan jenis pakan tertentu berdasarkan musim di daerah sentra dan non sentra sentra sapi perah di Kabupaten Enrekang, Sulawesi Selatan, 2009

\begin{tabular}{lcccc}
\hline \multirow{2}{*}{ Jenis pakan } & \multicolumn{2}{c}{ Sentra (orang) } & \multicolumn{2}{c}{ Non sentra (orang) } \\
\cline { 2 - 5 } & Kemarau & Hujan & Kemarau & Hujan \\
\hline Pakan kasar & & & & \\
Rumput gajah & 10 & 10 & 10 & 10 \\
Rumput raja & 0 & 0 & 2 & 2 \\
Kolonjono & 0 & 6 & 0 & 0 \\
Setaria & 2 & 4 & 3 & 3 \\
Lapangan & 0 & 3 & 0 & 0 \\
Benggala & 0 & 2 & 0 & 0 \\
Gamal & 3 & 1 & 6 & 2 \\
Kulit kopi & 0 & 0 & 2 & 0 \\
Kulit kakao & 0 & 0 & 1 & 0 \\
Batang pepaya & 0 & 0 & 6 & 0 \\
Batang pisang & 0 & 0 & 4 & 0 \\
Jerami padi & 4 & 4 & 3 & 1 \\
Jerami jagung dan & 6 & 6 & 0 & 2 \\
tongkolnya & 10 & 10 & 10 & 10 \\
Limbah kol & 0 & 0 & 0 & 3 \\
Limbah wortel & 0 & 0 & 3 & 0 \\
Daun ubi jalar & 0 & 0 & 0 & 10 \\
Jerami kacang & 10 & 0 & 0 & 0 \\
tanah & & & & \\
Bahan pakan & & & & \\
konsentrat & 0 & 0 & 10 & 0 \\
Ubi jalar & 0 & 0 & 6 & 0 \\
Ubi kayu & & 5 & 2 & 2 \\
Jagung & & & & \\
Dedak/bekatul & & & & \\
Ampas tahu & & & & \\
\hline & & & & \\
\hline
\end{tabular}

Asam amino bercabang mengalami dekarboksilasi dan deaminasi di dalam rumen, menjadi asam lemak bercabang (isobutirat, 2-metil butirat, isovalerat) yang sangat dibutuhkan untuk pertumbuhan mikroba rumen. Pemanfaatan daun singkong, baik segar, maupun yang diolah akan membantu mengatasi kualitas dan penyediaan pakan sapi perah di Kabupaten Enrekang.

Sumber pakan konsentrat di daerah nonsentra lebih beragam dibanding daerah sentra. Hanya 3 jenis sumber konsentrat yang sering digunakan peternak di daerah sentra, yaitu dedak, ampas tahu dan jagung. Peternak di daerah nonsentra mempunyai sumber konsentrat selain ketiga sumber tersebut, berupa ubi jalar dan ubi kayu, terutama produk sortiran yang tidak dikonsumsi masyarakat. Ubi jalar dan ubi kayu hasil sortiran sangat murah (Rp20.000/70 kg segar) pada musim panen, dan tersedia dalam jumlah yang melimpah. Peternak memanfaatkannya dengan mencacahnya dalam bentuk segar untuk diberikan kepada ternak. Berdasarkan pengalaman peternak, pemberian ubi jalar dan ubi kayu dapat meningkatkan produksi susu dan dangke dibanding menggunakan dedak.

Potensi pakan yang ada di Kabupaten Enrekang, baik di daerah sentra, maupun nonsentra, telah mampu menopang kebutuhan nilai nutrisi sapi perah. Hasil penelitian yang sama dikemukakan oleh Parikesit et al. (2005), bahwa peternak sapi perah skala kecil mampu memanfaatkan sumber daya biologi lokal guna memenuhi kebutuhan nutrisi serta untuk pengobatan dan pencegahan penyakit. Sutardi (1997) menambahkan bahwa, semakin beragam sumber pakan baik konsentrat maupun hijauan semakin meningkatkan kualitas pakan untuk memenuhi nilai nutrisi sapi perah. Potensi pakan di Kabupaten Enrekang cukup beragam, baik untuk sumber hijauan, maupun sumber konsentrat. Dibutuhkan teknologi yang tepat agar potensi pakan dapat dioptimalkan.

\section{Permasalahan Pakan}

Masalah utama yang dihadapi peternak sentra menurut persepsi suami dan istri adalah sama, yaitu ketidaktahuan formulasi pakan, kurangnya pengetahuan tentang kebutuhan nutrien sapi perah, ketidaktahuan manfaat bahan pakan, dan kualitas pakan yang rendah di musim kemarau (skor di atas 100) (Tabel 3). Menurut Gomes et al. (2007), pengetahuan yang rendah merupakan ciri yang melekat pada peternak sapi perah skala kecil. Mereka tidak memiliki pengetahuan tentang nilai nutrisi bahan pakan dan kebutuhan sapi perah serta tidak dilengkapi dengan program pencatatan yang baik.

Peternak di Kabupaten Enrekang melakukan usaha sapi perah secara turun temurun atau karena melihat keberhasilan temannya. Aspek pendidikan formal maupun informal, tidak mendukung pelaksanaan usaha mereka. Hanya 5\% saja yang menyelesaikan pendidikan di perguruan tinggi yang tidak berhubungan dengan usaha sapi perah dan sebanyak 32,5\% hanya SD dan SMP, sisanya $62,5 \%$ tamat SMA (Tabel 1). Diperlukan perubahan pengetahuan dan teknologi melalui teknologi yang murah dan tidak menciptakan ketergantungan dari luar 
Tabel 3. Skor permasalahan berdasarkan preferensi suami dan istri peserta participatory rural appraisal (PRA) di daerah sentra dan non sentra sapi perah, Kabupaten Enrekang, Sulawesi Selatan, 2009

\begin{tabular}{|c|c|c|c|c|c|c|}
\hline \multirow{2}{*}{ Uraian masalah* } & \multicolumn{3}{|c|}{ Sentra** } & \multicolumn{3}{|c|}{ Non sentra $^{* *}$} \\
\hline & Suami & Istri & Total & Suami & Istri & Total \\
\hline Kualitas pakan yang rendah & 51 & 56 & 107 & 19 & 18 & 37 \\
\hline Ketidaktahuan formulasi pakan sapi perah & 61 & 62 & 123 & 36 & 37 & 73 \\
\hline $\begin{array}{l}\text { Kekurangan pengetahuan kebutuhan nutrisi } \\
\text { sapi perah }\end{array}$ & 63 & 60 & 123 & 36 & 38 & 74 \\
\hline Ketidaktahuan manfaat bahan pakan & 62 & 60 & 122 & 39 & 37 & 76 \\
\hline Kelangkaan air & 28 & 34 & 62 & 49 & 47 & 96 \\
\hline Pakan yang tidak mencukupi & 42 & 42 & 84 & 56 & 54 & 110 \\
\hline Tidak diketahuinya pengawetan pakan & 36 & 34 & 70 & 68 & 71 & 139 \\
\hline $\begin{array}{l}\text { Kurangnya tenaga kerja untuk penyediaan } \\
\text { pakan }\end{array}$ & 17 & 12 & 29 & 57 & 58 & 115 \\
\hline
\end{tabular}

Keterangan: *Setiap peternak mengurutkan masalah yang paling penting dengan skor 8 dan masalah yang paling tidak penting dengan skor 1; **Total penilaian bobot masalah menurut 10 orang peternak (suami atau istri) di daerah sentra dan non sentra.

usahataninya. Melalui pemanfaatan potensi pakan lokal, akses peternak ke sumber pakan tinggi sehingga biaya dan ketergantungan peternak dapat diminimalisasi (Parikesit et al., 2005).

Rendahnya kualitas pakan dialami peternak sentra pada musim kemarau, saat rumput gajah sudah tidak dapat dipotong. Alternatifnya adalah menggunakan jerami padi dan jerami jagung beserta tongkolnya tanpa melakukan pengolahan. Akibatnya, produksi susu menurun drastis yang berimplikasi pada menurunnya produksi dangke. Menurut NRC (2001), sapi perah membutuhkan ransum dengan kandungan protein kasar dan total digestible nutrients (TDN) minimal 12\% dan 63\% untuk memproduksi 10-15 liter susu. Jerami padi dan jagung mempunyai kadar protein masing-masing 3,7\% dan 7\% serta kandungan TDN 39\% dan 52\% (Hartadi et al., 1986) sehingga secara kualitas sangat tidak mencukupi kebutuhan untuk produksi susu.

Masalah yang diungkapkan suami dan istri di daerah nonsentra juga sama, yaitu tidak diketahuinya teknologi pengawetan pakan, kurangnya tenaga kerja, serta pakan yang tidak mencukupi di musim kemarau (skor diatas 100) (Tabel 3). Terdapat 40\% peternak yang menempatkan kandang di daerah pegunungan, mengalami kelangkaan air di musim kemarau (skor di atas 90).

Produksi ubi jalar dan limbah hortikultura yang melimpah pada saat musim panen tidak dapat dimanfaatkan pada musim kemarau. Akibatnya, produksi susu meningkat sampai rata-rata 10 liter per ekor di musim hujan atau panen namun menurun drastis 3-4 liter di musim kemarau. Peternak di daerah nonsentra sangat membutuhkan teknologi pengawetan pakan guna memenuhi kekurangan pakan di musim kemarau.

Kekurangan tenaga kerja merupakan masalah peternak nonsentra (skor 115). Tenaga kerja lebih memilih pekerjaan lain, seperti buruh tani di kebun hortikultura atau perkebunan, dibanding di kandang. Mereka menganggap bekerja di kandang adalah pekerjaan kotor dan menjijikkan karena berhubungan dengan feses (kotoran ternak). Pemanfaatan tenaga kerja keluarga utamanya anak terkendala oleh letak kandang yang jauh dari rumah. Tidak seperti di daerah sentra, kandang terletak di dekat rumah sehingga sebelum berangkat ke sekolah anak peternak membersihkan kandang terlebih dahulu.

\section{Kebutuhan Teknologi Pakan}

Berdasarkan penilaian peternak terhadap masalah yang dihadapi serta potensi yang dimiliki, terdapat 7 teknologi pakan yang dibutuhkan peternak untuk diaplikasikan pada usaha sapi perah mereka (Tabel 4). Hasil preference ranking oleh suami dan istri di daerah sentra melahirkan 3 (tiga) urutan skor terbesar yang dibutuhkan peternak, yaitu teknologi complete feed, formulasi konsentrat, dan formulasi pakan (skor di atas 100).

Prioritas teknologi paling penting menurut istri adalah formulasi konsentrat yang berbeda dengan suami yang lebih menekankan pada pembuatan complete feed (Tabel 4). Perbedaan ini disebabkan oleh keterlibatan istri pada sektor downstream usaha sapi perah yang tinggi $(91,30 \%)$, yaitu dalam pembuatan dangke dan pemasarannya. Istri bertugas mengelola keuangan yang diperoleh dari menjual produk (dangke) sehingga teknologi yang dapat menekan biaya pakan, terutama konsentrat melalui formulasi konsentrat berbahan baku lokal untuk meningkatkan pendapatan, sangat diharapkan.

Lain halnya dengan suami, keterlibatannya dalam penyediaan sarana produksi dan kegiatan budidaya yang terkait dengan penyediaan dan pengantaran pakan bagi ternak (upstream dan on farm) dirasakan membutuhkan waktu dan energi yang cukup besar. Tingkat kesulitan semakin besar seiring dengan meningkatnya skala usaha. Suami sangat membutuhkan teknologi yang dapat membuat pekerjaan menjadi lebih efektif dan efisien, serta memudahkan dalam menangani manajemen usaha sapi perah.

Hasil penelitian ini sejalan dengan apa yang dikemukakan oleh Chi et al. (2007) yang menyatakan 
Tabel 4. Skor kebutuhan teknologi menurut preferensi suami dan istri peserta participatory rural appraisal (PRA) di daerah sentra dan non sentra sapi perah, Kabupaten Enrekang, Sulawesi Selatan, 2009

\begin{tabular}{|c|c|c|c|c|c|c|}
\hline \multirow{2}{*}{ Kebutuhan teknologi } & \multicolumn{3}{|c|}{ Sentra } & \multicolumn{3}{|c|}{ Non sentra } \\
\hline & Suami & Istri & Total & Suami & Istri & Total \\
\hline Pengawetan bahan pakan & 24 & 24 & 48 & 55 & 56 & 111 \\
\hline Peningkatan kualitas pakan & 49 & 42 & 91 & 27 & 27 & 54 \\
\hline Formulasi pakan & 56 & 53 & 109 & 46 & 43 & 89 \\
\hline Pengawetan limbah & 24 & 25 & 49 & 59 & 62 & 121 \\
\hline Complete feed & 58 & 59 & 117 & 55 & 55 & 110 \\
\hline Formulasi konsentrat & 53 & 60 & 113 & 26 & 25 & 51 \\
\hline Introduksi rumput unggul & 16 & 17 & 33 & 12 & 12 & 24 \\
\hline
\end{tabular}

Keterangan: *Setiap peternak mengurutkan kebutuhan teknologi yang paling penting dengan skor 8 dan kebutuhan teknologi yang paling tidak penting dengan skor $1 ;{ }^{* *}$ Total penilaian bobot masalah menurut 10 orang peternak (suami atau istri) di daerah sentra dan non sentra.

bahwa teknologi yang paling dibutuhkan bagi petani tergantung pada sudut pandang dan masalah terbesar yang dialami. Istri yang mengetahui dengan pasti aliran penerimaan dan pengeluaran dana (cash flow) karena menangani pemasaran dangke cenderung mengurangi pengeluaran dan memperbesar penerimaan. Sehingga dibutuhkan teknologi yang mampu mengurangi pengeluaran melalui penyediaan konsentrat yang lebih murah. Alternatif itu dapat dipenuhi melalui teknologi formulasi konsentrat bahan lokal. Suami yang bergelut dalam pelaksanaan usaha berpikir bagaimana agar pekerjaan yang dilakukan lebih efisien sehingga dibutuhkan teknologi yang menghemat tenaga kerja melalui penerapan complete feed.

Prioritas teknologi antara suami dengan istri di daerah nonsentra adalah sama. Tidak ada perbedaan urutan prioritas. Keduanya membutuhkan pengawetan limbah, pengawetan bahan pakan, dan pembuatan complete feed. Pengawetan limbah dimaksudkan untuk memanfaatkan limbah hortikultura dan tanaman pangan yang melimpah di STA sehingga dapat bertahan lama. Limbah hortikultura (wortel, buncis, dan kacang panjang) dan tanaman pangan (ubi jalar dan ubi kayu) sangat melimpah pada saat musim panen. Peternak hanya dapat memanfaatkan sebagian kecil saja pada musim panen dan sisanya terbuang percuma. Peternak sangat mengharapkan agar limbah yang melimpah pada musim panen dapat diolah dan diawetkan untuk disimpan dalam jangka waktu yang lama.

Teknologi pengawetan bahan pakan adalah mengawetkan ubi jalar dan ubi kayu sehingga produksi yang melimpah pada musim panen dapat dimanfaatkan untuk jangka waktu yang lama. Berdasarkan pengalaman peternak, pemberian ubi jalar dan ubi kayu mampu meningkatkan produksi susu dan dangke. Teknologi complete feed dimaksudkan untuk mereduksi penggunaan tenaga kerja karena sulitnya memperoleh tenaga kerja di daerah nonsentra. Melalui produksi complete feed pada musim hujan, peternak dapat menyimpannya untuk digunakan dalam jangka waktu lama dengan cara yang mudah sehingga tidak dibutuhkan tenaga kerja yang banyak.

\section{Sintesis Potensi, Permasalahan, dan Kebutuhan Teknologi Pakan}

Pengembangan teknologi pakan di daerah sentra agar diadopsi peternak, memerlukan upaya peningkatan pengetahuan peternak tentang kebutuhan nutrisi sapi perah di semua level umur dan status ternak. Diperlukan pemahaman tentang kandungan nutrisi bahan pakan lokal. Teknologi yang diperkenalkan kepada peternak sentra adalah membuat formulasi pakan dan formulasi konsentrat berbahan baku lokal. Salah satu model yang dapat digunakan dikemukakan oleh Roades \& Booth (1982), yaitu model farmer first-farmer last. Peternak melakukan sendiri teknologinya untuk diterapkan pada usahataninya agar mereka mengamati langsung serta mengadaptasikan teknologi sesuai dengan kondisi usahataninya. Model ini telah dibuktikan mampu meningkatkan adopsi hijauan unggul dan peningkatan skala usaha (Classen et al., 2008) dan meningkatkan pengetahuan petani dan adopsi teknologi di bidang manajemen hutan (Dolisca et al., 2006).

Pengembangan teknologi pengolahan limbah hortikultura dan sumber pakan lain yang melimpah di daerah nonsentra terkendala oleh kurangnya tenaga kerja yang mau bekerja di usaha sapi perah. Oleh karena itu, selain pengembangan teknologi pengolahan, diperlukan pula penguatan kelembagaan peternak. Gomez et al. (2007) membuktikan bahwa keterbatasan tenaga kerja dapat menghambat adopsi teknologi karena ketidakcukupan waktu mengerjakan pekerjaan tersebut, meskipun secara ekonomis menguntungkan dan secara teknis dapat dikerjakan.

Salah satu alternatif teknologi yang dapat diterapkan untuk mengawetkan limbah hortikultura adalah fermentasi dan pembuatan silase. Hasil penelitian Sandi et al. (2010) yang mengolah daun singkong menjadi silase dengan penambahan cairan rumen sapi dan Leuconostoc mesenteroides, meningkatkan kandungan protein kasar silase daun singkong menjadi 31,02\% dan $31,51 \%$, selain itu juga dapat menurunkan kandungan sianida pada daun sebesar $86,9 \%$. Pengawetan limbah sayuran seperti daun wortel dan daun kubis dapat dilakukan dengan pembuatan silase menggunakan 
bakteri asam laktat Lactobacillus delbrueckii yang mampu memperkecil kehilangan bahan kering, bahan organik, dan protein kasar (Muwakhid et al., 2007).

Guna mengatasi keterbatasan tenaga kerja di daerah nonsentra, pengembangan teknologi pengolahan pakan dan limbah dapat dilakukan melalui penguatan kelembagaan dengan membuat unit usaha yang dikelola oleh kelompok dalam melayani kebutuhan pakan setiap anggotanya. Usaha tersebut berfokus pada mengolah pakan dari limbah untuk disediakan ke peternak. Tenaga kerja dapat didatangkan dari luar daerah guna memenuhi kurangnya tenaga kerja di daerah nonsentra. Peternak membeli pakan dari kelompok dengan harga berdasarkan kesepakatan. Keuntungan yang diperoleh peternak adalah tersedianya pakan berkualitas sepanjang tahun, mengurangi kebutuhan tenaga kerja meskipun skala usaha ditingkatkan, serta termanfaatkannya potensi pakan yang berkualitas dan melimpah. Model ini dapat dikembangkan karena kelompok tani ternak di daerah sentra telah ada dan berkembang dalam melayani beberapa aktivitas, seperti arisan kelompok, pengadaan konsentrat melalui kelompok, serta pelayanan IB dan kesehatan hewan.

\section{KESIMPULAN}

Potensi pakan di Kabupaten Enrekang, baik di daerah sentra, maupun nonsentra, cukup untuk mendukung usaha sapi perah. Permasalahan pakan di daerah sentra meliputi kualitas pakan yang rendah dan rendahnya pengetahuan tentang kebutuhan nutrien serta formulasi ransum sapi perah, sedangkan permasalahan di daerah nonsentra meliputi kontinuitas pakan yang rendah, rendahnya pengetahuan tentang pengolahan dan pengawetan pakan serta kurangnya tenaga kerja. Kebutuhan teknologi untuk mengatasi masalah tersebut menurut persepsi peternak di daerah sentra adalah teknologi pengolahan pakan, formulasi ransum, dan pembuatan complete feed melalui peningkatan pengetahuan peternak. Daerah nonsentra membutuhkan pengolahan dan pengawetan pakan, serta teknologi pembuatan complete feed yang dikembangkan melalui penguatan kelembagaan peternak.

\section{DAFTAR PUSTAKA}

Altieri, M. A. 2002. Agroecology: The science of natural resource management for poor farmers in marginal enviroments. Agr. Ecosys. Environ. 93:1-24.

Baba, S. 2007. Kontribusi usaha ternak sapi perah terhadap pendapatan peternak sapi perah di Kecamatan Cendana Kabupaten Enrekang. Jurnal Vegeta 1: 23-28.

Baba, S. 2008. Analisis tingkat adopsi usaha ternak sapi perah di kabupaten Enrekang. Jurnal Vegeta 2: 14-19.

Biggs, S. \& G. Smith. 1998. Beyond methodologies: coalition-building for participatory technology development. World Develop. 26: 239-248.

Chambers, R. 1994. The origin and practice of participatory rural appraisal. World Develop. 22: 953-969.

Chambers, R. 2007. Participation and poverty. Development 50: $20-25$

Chi, T. T. N., P. V. Liem, \& T. Paris. 2007. Farmers participation in rice variety selection. Omonrice 15: 159-163.
Classen, L., S. Humphries, J. Fitzimons, \& S. Kaaria. 2008. Opening participatory spaces for the most marginal: Learning from collective action in the Honduras hillsides. World Develop. 36: 2402-2420.

Devendra, C. 2007. Constraint analysis to improve integrated dairy production system in developing countries: Importance of participatory rural appraisal. Trop. Anim. Health Prod. 39: 549-556.

Dinas Pertanian Daerah Enrekang. 2008. Statistik Peternakan Kabupaten Enrekang, Enrekang.

Dolisca, F., D. R. Carter, J. M. McDaniel, D. A. Shannon, \& C. M. Jolly. 2006. Factor influencing farmers' participation in forestry management programs: A case study from Haiti. Forest Ecol. Manag. 236: 324-331.

Erwanto, Muhtarudin, Liman, \& Y. Widodo. 2001. Penggunaan tepung daun singkong sebagai sumber asam amino rantai bercabang dalam ransum ternak ruminansia secara in vitro. Sainteks 8:267-273.

Gomez, C., M. Fernandez, I. Salazar, I. Saldana, \& H. Heredia. 2007. Improvement of small dairy producers in the central coast of Peru. Trop. Anim. Health Prod. 39: 611-618.

Hagman, J., E. Chuma, K. Murwira, \& M. Connoly. 2000. Learning Together Through Participatory Extension: A Guide to an Approach Developed in Zimbabwe. $2^{\text {nd }}$ Edition. Departement of Agricultural, Technical and Extension Services Zimbabwe, Harara.

Hartadi, H., S. Reksohadiprodjo, \& A. D. Tillman. 1986. Tabel Komposisi Pakan untuk Indonesia. Gadjah Mada University Press, Yogyakarta.

Havlikova, M., C. Kroeze, \& M. A. J. Huijbregts. 2008. Enviromental and health impact by dairy cattle livestock and manure management in the Czech Republic. Sci.Tot. Environ. 396: 121-131.

Loader, R. \& L. Amartya. 1999. Participatory rural appraisal: extending the research methods base. Agr. Syst. 62: 73-85.

Mastuti, S. \& N. N. Hidayat. 2009. Peranan tenaga kerja perempuan dalam usaha ternak sapi perah di Kabupaten Banyumas. Animal Prod. 11: 40-47.

Mikkelsen, B. 2003. Metode penelitian Partisipatoris dan Upaya-Upaya Pemberdayaan: Sebuah Buku Pegangan bagi para Praktisi Lapangan. Terjemahan: M. Nalle, Yayasan Obor Indonesia, Jakarta.

Mudikdjo, K., U. Sehabuddin, \& R. Pambudi. 2001. Analisis ekonomi usaha sapi perah di wilayah Propinsi Jawa Barat. Med. Pet. Edisi Khusus 24: 57-66.

Muwakhid, B., Soebarinoto, O. Sjofjan, \& A. Am. 2007. Pengaruh penggunaan inokulum bakteri asam laktat terhadap kualitas silase limbah sayuran pasar sebagai bahan pakan. J. Peng. Pet. Trop. 32: 159-166

National Research Council. 2001. Nutrient Requerement of Dairy Cattle. National Academy Press, Washington D.C.

Parikesit, K. Takeuchi, A. Tsunekawa, \& O. S. Abdoellah. 2005. Resource analysis of small scale dairy production system in an Indonesian village - a case study. Agr. Ecosys. Environ. 105: 541-554.

Peacock, C. 2005. Goaths - A pathway out of poverty. Small Ruminant Res. 60: 179-186.

Rekhis, J., F. Saaidane, M. Laamouri, K. B. Hamida., W. Mabrouk, \& N. Slimane. 2007. Participatory rural appraisal in smallholder dairy systems in Tunisia. Trop. Anim. Health Prod. 39: 619-626.

Rhoades, R. E. \& R. H. Boath. 1982. Farmer-back-to-farmer: a model for generating acceptable agriculture technology. Agr. Admin. 11: 127-137

Sandi, S., E. B. Laconi, A. Sudarman, K. G. Wiryawan, \& D. Mangundjaja. 2010. Kualitas nutrisi silase berbahan baku singkong yang diberi enzim cairan rumen dan Leuconostoc mesenteroides. Med. Pet. 33: 25-30.

Shamsuddin, M., M. M. Alam, M. S. Hossein, W. J. Goodner, 
F. Y. Bari, T. U. Ahmed, M. M. Hossain, \& A. H. M. S. I. Khan. 2007. Participatory rural appraisal to identify needs and prospect of market-oriented dairy industries in Bangladesh. Trop. Anim. Health Prod. 39: 567-581.

Sutardi, T. 1997. Peluang dan Tantangan Pengembangan IlmuIlmu Nutrisi Ternak. Orasi ilmiah Guru Besar Tetap Ilmu Nutrisi Ternak. Fakultas Peternakan Institut Pertanian Bogor, Bogor.

Thabrew, L., A. Wiek, \& R. Ries. 2009. Enviromental decision making in multi-stakeholder context: applicability of life cycle thinking in development planning and implementation. J. Clean. Prod. 17: 67-76.
Vaarst, M., D. K. Byarugaba, J. Nakavuma, \& C. Laker. 2007. Participatory livestock farmer training for improvement of animal health in rural and peri-urban smallholder dairy herds in Jinja, Uganda. Trop. Anim. Health Prod. 39: 1-11

Walters, B. B., A. Cadelina, A. Cardano, \& E. Visitacion. 1999. Community history and rural development: why some farmers participate more readily than others. Agr. Syst. 59: 193-214.

Yusdja, Y. 2005. Kebijakan ekonomi industri agribisnis sapi perah di Indonesia. Analisis Kebijakan Pertanian 3: 257-268. 